\title{
Influence of Phosphorus and Boron Application on Yield, Quality, Nutrient Content and Their Uptake by Green Gram (Vigna radiate L.)
}

\author{
Nidhi Kamboj* and R.S. Malik \\ Department of Soil Science, CCSHAU, Hisar-125004, Haryana, India \\ *Corresponding author
}

\section{A B S T R A C T}

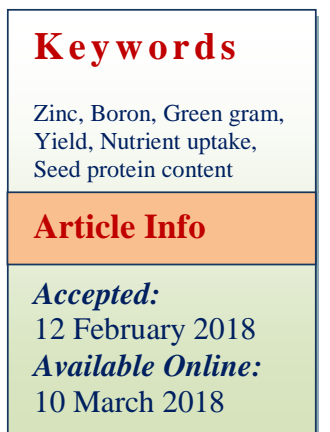

\section{Introduction}

In intensive cropping system of the country mungbean (vigna radiate L.) has special importance for its short growth period. Mungbean being a leguminous crop, responds well to added phosphorus. An adequate phosphorus supply must be satisfied for the legumes, to fix nitrogen in soil, other factors being adequate. Phosphorus (P) is an essential plant nutrient required for optimum crop production. Plants need phosphorus for growth, utilization of sugar and starch, photosynthesis, nucleus formation and cell division Atif et al., (2014). Boron's (B) role within the plant includes cell wall synthesis, sugar transport, cell division, differentiation, membrane functioning, root elongation, regulation of plant hormone levels and generative growth of plants Marschner (1995). Phosphorus deficiency causes yield reduction by limiting plant growth Poehlman (1991). It influences nutrient uptake by promoting root growth and nodulation Singh and Singh, (1994). Among the pulses, it is best in nutritional value having about $51 \%$ carbohydrates, $26 \%$ proteins, $4 \%$ minerals and $3 \%$ vitamins Kaul (1982). The response to a particular nutrient not only depends on its own level but also on the levels of other nutrients present in soil. Interaction occur when the level of one production factor influence the response to other factor. These Interactions may be Synergetics (positive) leading to the 
increased availability of other plant nutrient or Antagonistics (negative) in which availability of other plant nutrient adversely affected. If there is neither positive nor negative effect on availability of other nutrient, it is considered as non interaction. Seed yield and its quality in crop plants are greatly influenced by both macro and micronutrients Jasim et al., (2014). Many researchers reported that $\mathrm{P}$ and $\mathrm{B}$ have significant synergetics effect in improving the growth, yield and quality of plant species Kaya et al., (2009); YuFan et al., (2012). Therefore, the present study was undertaken to see the interaction effect of $\mathrm{P}$ and $\mathrm{B}$ on the yield and quality of green gram.

\section{Materials and Methods}

A screen house experiment was conducted during summer season at CSSHAU, Hisar. Bulk soil samples of $(0-15 \mathrm{~cm}$ depth) were collected from village Balsamand district Hisar. The soil sample was air dried ground and passed through $2 \mathrm{~mm}$ sieve and analysed for physico-chemical properties and initial nutrients status using standard procedure. Four $\mathrm{kg}$ thoroughly mixed soil was filled in each pot and placed in completely randomized block design in the screen house. Five levels of phosphorus $0,25,50,75$ and $100 \mathrm{mg} \mathrm{P}_{2} \mathrm{O}_{5}$ $\mathrm{kg}^{-1}$ soil through Potassium orthophosphate $\left\{\mathrm{KH}_{2} \mathrm{PO}_{4}\right\}$ and four level of boron $0,0.25,0.5$

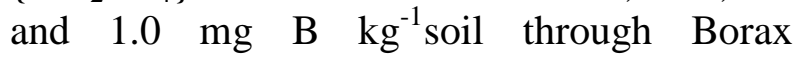
$\left\{\mathrm{Na}_{2} \mathrm{~B}_{4} \mathrm{O}_{7} \cdot 10 \mathrm{H}_{2} \mathrm{O}\right\}$ were applied. Recommended doses of nitrogen and phosphorus were uniformly applied as basal in each pot. Eight seeds of green gram (cv: Asha) were seeded in each pot and after thinning four uniform plants per pots were allowed to grow up to maturity. At physiological maturity plants samples were collected, air dried and in oven at $65 \pm 2{ }^{\circ} \mathrm{C}$ till a constant weight was obtained. The dry matter and seed yield was also recorded. For the estimation of $\mathrm{P}$ and $\mathrm{B}$ content in plants as well as seed, samples were digested with diacid mixture $\left(\mathrm{HNO}_{3}\right.$ and
$\mathrm{HClO}_{4}$ ) in 4:1 ratio for analysis of $\mathrm{Zn}$ and $\mathrm{B}$ content and their uptake was computed accordingly. Seeds were also digested in a diacid mixture of sulphuric and perchloric acid in the ratio of 9:1 for the analysis of total $\mathrm{N}$ in colorimetric (Nesslar's reagent) method. Crude protein in green gram seed was computed by multiplying total seed $\mathrm{N}$ with 6.25 .

\section{Results and Discussion}

\section{Seed and straw yield}

The seed and straw yield of green gram significantly increases with the increased level of boron up to $0.5 \mathrm{mg} \mathrm{B} \mathrm{kg}^{-1}$ i.e. $8.18 \mathrm{~g} \mathrm{pot}^{-1}$ and $58.91 \mathrm{~g} \mathrm{pot}^{-1}$ over control i.e. $4.56 \mathrm{~g} \mathrm{pot}^{-1}$ and $39.45 \mathrm{~g} \mathrm{pot}^{-1}$, respectively. Subedi and Yadav (2013), also reported higher grain yield of mung-bean $\left(1583 \mathrm{~kg} \mathrm{ha}^{-1}\right)$. After the level of boron $0.5 \mathrm{mg} \mathrm{B} \mathrm{kg}^{-1}$, a significant decrease was observed in seed as well as in straw yield of green gram due to toxicity of high level of boron i.e. $1.0 \mathrm{mg} \mathrm{kg}^{-1}$. Padbhushan and Kumar (2014), noticed that out of all four levels of soil applied boron viz. 0.5, 0.75, 1.0 and 1.5 mg B kg${ }^{-1}$ and two levels of foliar viz. 0.1 and $0.2 \%$ borax solution, $0.5 \mathrm{mg} \mathrm{kg}^{-1}$ soil applied boron is best treatment while $0.1 \%$ is best foliar treatment.

Similarly, in case of $\mathrm{P}$ application along with $\mathrm{B}$, the seed and straw yield of green gram increased significantly upto $9.39 \mathrm{~g} \mathrm{pot}^{-1}$ in seed and $66.83 \mathrm{~g} \mathrm{pot}^{-1}$ in straw with increasing level of P over control (4.56 $\mathrm{g} \mathrm{pot}^{-1}$ ) (Table 1). The interaction effect of phosphorus and boron on seed yield was significant. The highest seed yield (10.18 $\left.\mathrm{g} \mathrm{pot}^{-1}\right)$ was found when $0.5 \mathrm{mg} \mathrm{B} \mathrm{kg}^{-1}$ applied along with 100 $\mathrm{mg} \mathrm{P} \mathrm{kg}{ }^{-1}$ over control i.e. (4.56 $\mathrm{g} \mathrm{pot}^{-1}$ ). Alam et al., (2010), also conducted an experiment with four levels of $\mathrm{P}\left(0,10,20\right.$ and $\left.30 \mathrm{~kg} \mathrm{ha}^{-1}\right)$ and three levels of $\mathrm{B}\left(0,1\right.$ and $\left.2 \mathrm{~kg} \mathrm{ha}^{-1}\right)$ revealed that yield and yield attributing 
characters of summer mung-bean influenced significantly by the application of phosphorus $(\mathrm{P})$ and boron $(\mathrm{B})$.

\section{Boron content}

The highest concentration of boron in seed and straw of green gram was obtained when $\mathrm{P}$ was applied @ $100 \mathrm{mg} \mathrm{P} \mathrm{kg}^{-1}$ and B @ 1 mg B $\mathrm{kg}^{-1}$ of soil. The significant increase in boron content of seed and straw of green gram ranges from $47.43 \mathrm{mg} \mathrm{kg}^{-1}$ and $49.75 \mathrm{mg} \mathrm{kg}^{-1}$ boron in control to $63.99 \mathrm{mg} \mathrm{kg}^{-1}$ and 60.28 $\mathrm{mg} \mathrm{kg}^{-1}$ boron at $100 \mathrm{mg} \mathrm{P} \mathrm{kg}{ }^{-1}$ of soil. Singh et al., (2006), found an increase in available $\mathrm{P}_{2} \mathrm{O}_{5}$ decreased the magnitude of $\mathrm{B}$ deficiency by $42 \%$ when available $\mathrm{P}_{2} \mathrm{O}_{5}$ was less than 30 $\mathrm{kg} \mathrm{ha}{ }^{-1}, 38 \%$ when $\mathrm{P}_{2} \mathrm{O}_{5}$ ranging from 30-40 $\mathrm{kg} \mathrm{ha}{ }^{-1}$ and $29 \%$ above $40 \mathrm{~kg} \mathrm{P}_{2} \mathrm{O}_{5} \mathrm{ha}^{-1}$. Similarly, with increasing level of boron application there was significant increase in boron content in seed and straw of green gram from $39.59 \mathrm{mg} \mathrm{kg}^{-1}$ and $45.16 \mathrm{mg} \mathrm{kg}^{-1}$ boron in control to $66.74 \mathrm{mg} \mathrm{kg}^{-1}$ and $62.72 \mathrm{mg} \mathrm{kg}^{-1}$ boron at highest level of applied boron i.e. 1.0 $\mathrm{mg} \mathrm{kg}^{-1}$ of soil, respectively (Table 2) The combined application of phosphorus and boron shows significant higher boron content (77.38 mg B kg ${ }^{-1)}$ in seed and $(69.50 \mathrm{mg} \mathrm{B}$ $\mathrm{kg}^{-1}$ ) in straw of green gram when $1 \mathrm{mg} \mathrm{B} \mathrm{kg}^{-1}$ was applied along with $100 \mathrm{mg} \mathrm{P} \mathrm{kg}^{-1}$.

\section{Seed and straw phosphorus concentration}

The phosphorus content in seed as well as straw of green gram increases with application of graded level of phosphorus and it ranges from $0.28 \%$ and $0.06 \%$ under control to $0.51 \%$ and $0.25 \%$ at higher dose of $\mathrm{P}$ applied (100 $\mathrm{mg} \mathrm{P} \mathrm{kg}^{-1}$ ), respectively (Table 3 ). Application of increasing level of boron also increases the phosphorus concentration in seed of green gram significantly from $0.32 \%$ in seed and $0.13 \%$ in straw under control to $0.48 \%$ in seed and $0.17 \%$ in straw when B was applied @ $1.0 \mathrm{mg} \mathrm{kg}^{-1}$ of soil. A significant interaction effect of $\mathrm{P}$ and $\mathrm{B}$ application on seed and straw $\mathrm{P}$ content was observed with the combined application of phosphorus and boron. The maximum phosphorus concentration $(0.59 \%)$ in seed and $(0.27 \%)$ in straw of green gram was observed when $\mathrm{P}$ and $\mathrm{B}$ applied in combination of $100 \mathrm{mg} \mathrm{P} \mathrm{kg}^{-1}$ and $1 \mathrm{mg} \mathrm{B} \mathrm{kg}^{-1}$ of soil.

\section{Boron uptake by seed and straw}

Similar to yield and concentration of both, phosphorus and boron application also enhance boron uptake in seed of green gram significantly. Boron uptake in seed increased from $269.38 \mu \mathrm{g} \mathrm{pot}^{-1}$ in control to $613.76 \mu \mathrm{g}$ $\operatorname{pot}^{-1}$ when $100 \mathrm{mg} \mathrm{P} \mathrm{kg}{ }^{-1}$ of soil was applied. Likewise, with the increasing level of boron application from 0 to $1.0 \mathrm{mg} \mathrm{kg}^{-1}$, the uptake of boron also increases significantly from $249.64 \mu \mathrm{g} \mathrm{pot}^{-1}$ to $546.90 \mu \mathrm{g}$ pot $^{-1}$ when B was applied @ $1.0 \mathrm{mg} \mathrm{B} \mathrm{kg}^{-1}$ of soil (Figure 1). These results are in close agreement with the findings of Kumar et al., (2009) in which increase in boron uptake up to application of 4 $\mathrm{kg} \mathrm{B} \mathrm{ha}{ }^{-1}$ and $90 \mathrm{~kg} \mathrm{P}_{2} \mathrm{O}_{5} \mathrm{ha}^{-1}$ by grain and straw of Lentil was noticed. This increase may be the result of increased grain and straw production with the addition $\mathrm{B}$ and $\mathrm{P}$ which enhance their availability in soil. The interaction effect of $\mathrm{P}$ and $\mathrm{B}$ on boron uptake by seed of green gram was found significant and highest $\mathrm{B}$ uptake $\left(784.46 \mu \mathrm{g} \mathrm{pot}^{-1}\right)$ was found when phosphorus and boron were applied in a combination of $\mathrm{P}_{100} \mathrm{~B}_{1.0}$. The uptake of boron in straw of green gram increases at each level of phosphorus and

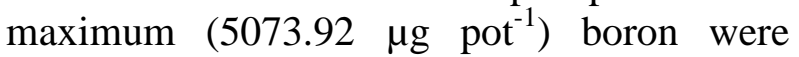
found at their highest levels over control i.e. 2685.29 $\mu \mathrm{g} \operatorname{pot}^{-1}$ where no application of either P or B was done. Graded level of applied boron also enhances the boron uptake significantly in straw of green gram. Highest uptake of B on account of B application was found $3778.71 \mu \mathrm{g} \mathrm{pot}^{-1}$ when B was applied @ $1.0 \mathrm{mg} \mathrm{kg}^{-1}$ over control i.e. $2043.72 \mu \mathrm{g} \mathrm{pot}^{-1}$. 


\begin{tabular}{|c|c|c|c|c|c|}
\hline \multirow{2}{*}{$\begin{array}{c}\text { Phosphorus } \\
\text { level } \\
\left(\mathrm{mg} \mathrm{kg}^{-1}\right)\end{array}$} & \multicolumn{4}{|c|}{ Boron Level $\left(\mathrm{mg} \mathrm{kg}^{-1}\right)$} & \multirow[t]{2}{*}{ Mean } \\
\hline & 0 & 0.25 & 0.5 & 1.0 & \\
\hline \multicolumn{6}{|c|}{ Seed yield } \\
\hline$\overline{0}$ & 4.56 & 5.50 & 6.09 & 5.04 & 5.29 \\
\hline 25 & 5.22 & 6.23 & 7.08 & 7.02 & 6.39 \\
\hline 50 & 6.47 & 7.26 & 8.24 & 8.16 & 7.53 \\
\hline 75 & 7.22 & 8.20 & 9.31 & 9.11 & 8.46 \\
\hline 100 & 7.92 & 9.30 & 10.18 & 10.14 & 9.39 \\
\hline Mean & 6.28 & 7.29 & 8.18 & 7.89 & \\
\hline CD at $5 \%$ & $\mathrm{P}=0.18$ & $B=0.16$ & $\mathrm{P} \times \mathrm{B}=0.36$ & & \\
\hline \multicolumn{6}{|c|}{ Straw yield } \\
\hline $\mathbf{0}$ & 32.81 & 39.62 & 43.89 & 41.48 & 39.45 \\
\hline 25 & 37.61 & 44.83 & 51.00 & 50.26 & 45.93 \\
\hline 50 & 46.58 & 52.29 & 59.35 & 58.75 & 54.24 \\
\hline 75 & 51.96 & 59.07 & 67.03 & 65.62 & 60.92 \\
\hline 100 & 57.05 & 66.98 & 73.27 & 70.00 & 66.83 \\
\hline Mean & 45.20 & 52.56 & 58.91 & 57.22 & \\
\hline CD at $5 \%$ & $\mathrm{P}=1.32$ & $\mathrm{~B}=1.18$ & $\mathrm{P} \times \mathrm{B}=\mathrm{N} . \mathrm{S}$ & & \\
\hline
\end{tabular}

Table.2 Effect of phosphorus and boron application on green gram seed and straw boron content

\begin{tabular}{|c|c|c|c|c|c|}
\hline \multirow{2}{*}{$\begin{array}{c}\text { Phosphorus } \\
\text { level } \\
\left(\mathrm{mg} \mathrm{kg}^{-1}\right)\end{array}$} & \multicolumn{4}{|c|}{ Boron Level $\left(\mathrm{mg} \mathrm{kg}^{-1}\right)$} & \multirow[t]{2}{*}{ Mean } \\
\hline & 0 & 0.25 & 0.5 & 1.0 & \\
\hline \multicolumn{6}{|c|}{ Boron content ( $\left.\mathrm{mg} \mathrm{kg}^{-1}\right)$ in seed } \\
\hline 0 & 38.73 & 45.33 & 55.67 & 52.00 & 47.43 \\
\hline 25 & 38.80 & 51.33 & 58.80 & 64.83 & 53.44 \\
\hline 50 & 39.02 & 55.83 & 62.80 & 68.47 & 56.53 \\
\hline 75 & 39.83 & 57.70 & 70.50 & 71.02 & 59.76 \\
\hline 100 & 41.57 & 61.20 & 75.83 & 77.38 & 63.99 \\
\hline Mean & 39.59 & 54.278 & 64.72 & 66.74 & \\
\hline CD at $5 \%$ & $\mathrm{P}=1.58$ & $\mathrm{~B}=1.42$ & $\mathrm{P} \times \mathrm{B}=3.17$ & & \\
\hline \multicolumn{6}{|c|}{ Boron content ( $\mathrm{mg} \mathrm{kg}^{-1}$ ) in straw } \\
\hline 0 & 44.30 & 48.50 & 51.50 & 54.70 & 49.75 \\
\hline 25 & 45.10 & 54.37 & 56.20 & 60.20 & 53.97 \\
\hline 50 & 45.53 & 57.90 & 58.60 & 62.60 & 56.16 \\
\hline 75 & 45.27 & 59.70 & 61.60 & 66.60 & 58.29 \\
\hline 100 & 45.60 & 61.80 & 64.20 & 69.50 & 60.28 \\
\hline Mean & 45.16 & 56.45 & 58.42 & 62.72 & \\
\hline CD at $5 \%$ & $\mathrm{P}=1.34$ & $\mathrm{~B}=1.19$ & $\mathrm{P} \times \mathrm{B}=2.68$ & & \\
\hline
\end{tabular}




\begin{tabular}{|c|c|c|c|c|c|}
\hline \multirow{2}{*}{$\begin{array}{c}\text { Phosphorus } \\
\text { level } \\
\left(\mathrm{mg} \mathrm{kg}^{-1}\right)\end{array}$} & \multicolumn{4}{|c|}{ Boron Level (mg kg $\left.{ }^{-1}\right)$} & \multirow[t]{2}{*}{ Mean } \\
\hline & $\mathbf{0}$ & 0.25 & 0.5 & 1.0 & \\
\hline \multicolumn{6}{|c|}{ phosphorus content $(\%)$ in seed } \\
\hline 0 & 0.23 & 0.25 & 0.31 & 0.32 & 0.28 \\
\hline 25 & 0.26 & 0.28 & 0.37 & 0.37 & 0.32 \\
\hline 50 & 0.33 & 0.35 & 0.46 & 0.53 & 0.42 \\
\hline 75 & 0.36 & 0.45 & 0.51 & 0.58 & 0.48 \\
\hline 100 & 0.42 & 0.47 & 0.56 & 0.59 & 0.51 \\
\hline Mean & 0.32 & 0.36 & 0.44 & 0.48 & 0.28 \\
\hline CD at $5 \%$ & $\mathrm{P}=0.02$ & $\mathrm{~B}=0.01$ & $\mathrm{P} \times \mathrm{B}=0.03$ & & \\
\hline \multicolumn{6}{|c|}{ Phosphorus content (\%) in straw } \\
\hline 0 & 0.05 & 0.06 & 0.07 & 0.07 & 0.06 \\
\hline 25 & 0.09 & 0.09 & 0.10 & 0.10 & 0.09 \\
\hline 50 & 0.12 & 0.15 & 0.16 & 0.18 & 0.15 \\
\hline 75 & 0.17 & 0.20 & 0.20 & 0.23 & 0.20 \\
\hline 100 & 0.21 & 0.24 & 0.26 & 0.27 & 0.25 \\
\hline Mean & 0.13 & 0.15 & 0.16 & 0.17 & \\
\hline CD at $5 \%$ & $P=0.01$ & $\mathrm{~B}=0.01$ & $\mathrm{P} \times \mathrm{B}=0.02$ & & \\
\hline
\end{tabular}

Table.4 Effect of phosphorus and boron application on seed protein content (\%) of green gram

\begin{tabular}{|c|c|c|c|c|c|}
\hline \multirow{2}{*}{$\begin{array}{c}\text { Phosphorus } \\
\left.\text { level ( } \mathrm{mg} \mathrm{kg}^{-1}\right)\end{array}$} & \multicolumn{4}{|c|}{ Boron Level (mg kg ${ }^{-1}$ ) } & \multirow[t]{2}{*}{ Mean } \\
\hline & 0 & 0.25 & 0.5 & 1.0 & \\
\hline 0 & 16.67 & 19.01 & 20.83 & 19.01 & 18.88 \\
\hline 25 & 18.13 & 21.88 & 22.93 & 20.21 & 20.79 \\
\hline 50 & 20.46 & 21.44 & 23.67 & 20.21 & 21.45 \\
\hline 75 & 21.25 & 23.84 & 25.83 & 21.25 & 23.04 \\
\hline 100 & 22.35 & 24.08 & 25.57 & 22.29 & 23.57 \\
\hline Mean & 19.77 & 22.05 & 23.77 & 20.59 & \\
\hline CD at $5 \%$ & $\mathrm{P}=1.03$ & $B=0.92$ & $\mathrm{P} \times \mathrm{B}=\mathrm{N} . \mathrm{S}$. & & \\
\hline
\end{tabular}



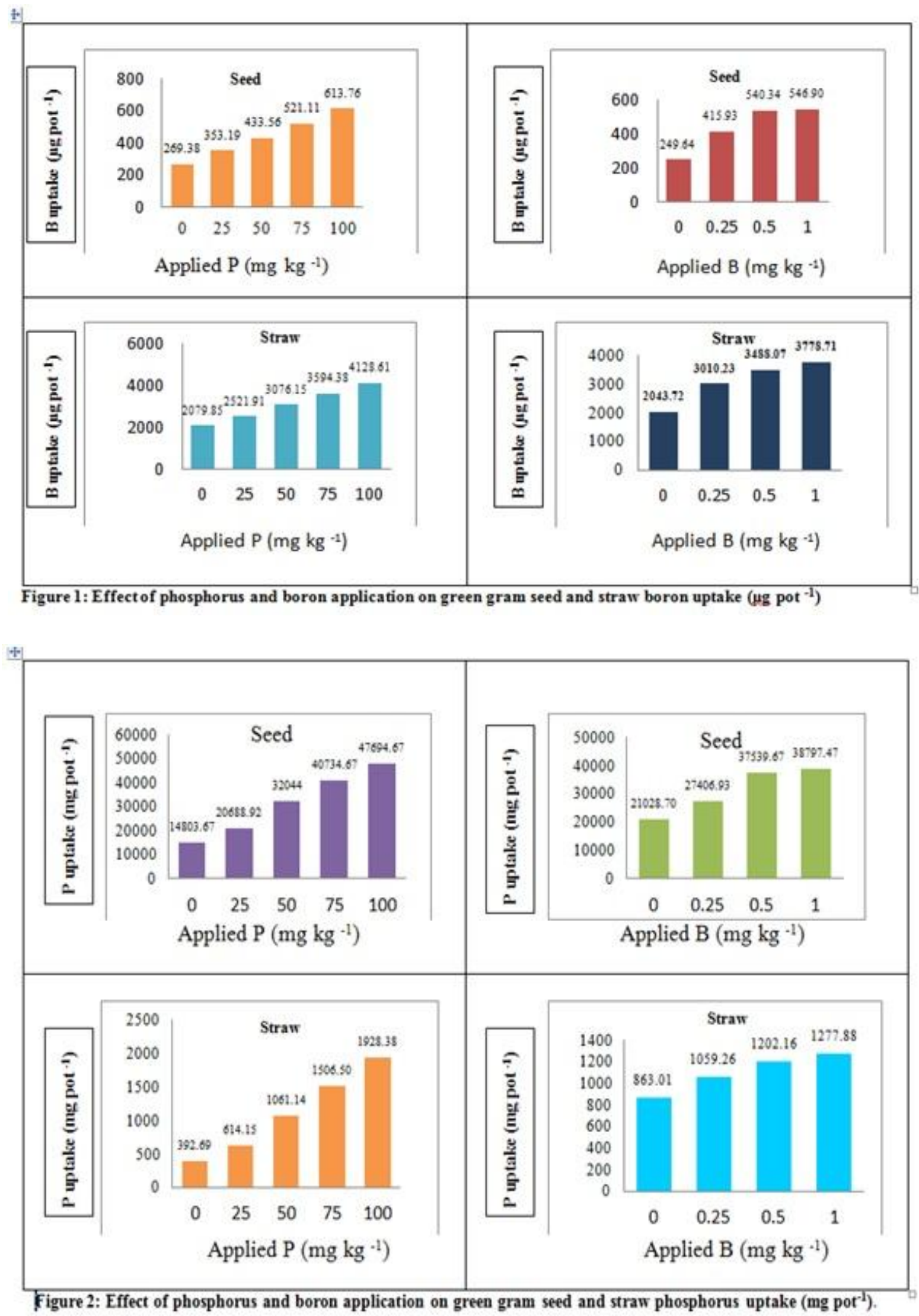


\section{Seed and straw phosphorus uptake}

Effect of $\mathrm{P}$ and $\mathrm{B}$ application on $\mathrm{P}$ uptake in seed and straw of green gram was shown in (Figure 2) which revealed that with increase in phosphorus application along with increasing level of $\mathrm{B}$, the uptake of phosphorus increases from $14803.67 \mathrm{mg} \mathrm{pot}^{-1}$ in control to $47694.67 \mathrm{mg} \mathrm{pot}^{-1}$ with the application of $100 \mathrm{mg} \mathrm{P} \mathrm{kg}^{-1}$ and from $21028.7 \mathrm{mg} \mathrm{pot}^{-1}$ under control to 38797.47 $\mathrm{mg}$ pot ${ }^{-1}$ at $1 \mathrm{mg} \mathrm{B} \mathrm{kg}^{-1}$ in seed. Similarly, in straw also, increased level of both $\mathrm{P}$ and $\mathrm{B}$ application increase the $\mathrm{P}$ uptake and it varies from $392.69 \mathrm{mg}$ pot $^{-1}$ under control to 1928.38 at $100 \mathrm{mg} \mathrm{P} \mathrm{kg}^{-1}$ application with boron application from $863.01 \mathrm{mg} \mathrm{pot}^{-1}$ under control to $1277.87 \mathrm{mg} \mathrm{kg}^{-1}$ at $1 \mathrm{mg} \mathrm{B} \mathrm{kg}$. Mallick and Raj (2015), observed that Phosphorus and boron application increased the seed uptake of $\mathrm{P}$ in rapseed and this increased in $\mathrm{P}$ uptake could be the response of variation in the availability of these nutrients in the soil and partly due to priming effect of one nutrient on the other on the uptake. Rana et al., (2005), also reported similar effect of nutrient application. YuFan et al., (2012), observed that $\mathrm{B}$ application increased $\mathrm{P}$ uptake by plant. The interactive effect of $P$ and $\mathrm{B}$ application on $\mathrm{P}$ uptake in seed of green gram was found significant. Highly significant $\mathrm{P}$ uptake by seed of green gram was noticed at $\mathrm{P}_{100} \mathrm{~B}_{0.5}$ level. Whereas, in straw the interactive effect of $\mathrm{P}$ and $\mathrm{B}$ application was found non-significant.

\section{Seed protein content}

The crude protein content in seed of green gram increases significantly from 18.88 to $23.57 \%$ when P was applied @ $100 \mathrm{mg} \mathrm{kg}^{-1}$ (Table 4). Deo and Khaldelwal (2009), found that application of $\mathrm{P}$ increased the number of nodules per plant of chickpea and protein content in grain. Whereas, with the application of boron the crude protein content in seed of green gram increases significantly up to the level of $0.5 \mathrm{mg} \mathrm{B} \mathrm{kg}^{-1}$ over control i.e. $19.77 \%$ and after that there was a decrease in protein content occur with further addition of boron fertilizer. Ganie et al., (2014), reported a significant increase in the crude protein content of French bean with graded level of boron application upto $1 \mathrm{mg} \mathrm{B} \mathrm{kg} \mathrm{m}^{-1}$ which is statistically at par with $1.5 \mathrm{mg} \mathrm{B} \mathrm{kg}^{-1}$ application. This significant rise in crude protein content is probably due to the vital role that boron plays in protein and nucleic acid metabolism Debnath and Ghosh, (2011). No significant difference was found in crude protein content of green gram with the combined application of both phosphorus and boron.

\section{Acknowledgement}

The authors are thankful to the Department of Soil Science, CCS Haryana Agricultural University, Hisar for providing the financial support and all the necessary facilities to complete the experiment.

\section{References}

Alam, M.R., Ali, M.A., Rafiquzzaman, S., Ahmed, B.and Bazzaz, M. (2010). Effect of phosphorus and boron on the performance of summer mungbean in high Ganges river floodplain soil. Journal of Agroforestry and Environment.3: 183-186.

Atif, M.J., Shaukat, S.A., Shah, S.Z.A., Choudhary, Y.A., and Shaukat, S.K. (2014) Effect of different levels of phosphorus on growth and productivity of pea (Pisum sativum L.) cultivars grown as offseason under rawalakot azad Jammu and Kashmir conditions. Journal of Recent Advances in Agriculture. 2: 252-257.

Debnath, P., and Ghosh, S. K. (2011). Determination of critical limit of available boron for rice in terai zone soils of West Bengal. Journal of the Indian Society of Soil Science. 59: 82-86. 
Deo, C., and Khaldelwal, R.B. (2009). Effect of P and $\mathrm{S}$ Nutrition on yield and quality of chickpea (Cicer arietinum L.). Journal of the Indian Society of Soil Science. 57: 352356.

Ganie Mumtaz, A., Akhter, F., Bhat, M.A. and Najar, G.R. (2014). Growth, yield and quality of French bean (phaseolus vulgaris L.) as influenced by sulphur and boron application on inceptisols of Kashmir. The bioscan 9: 513-518.

Jasim A.H. and Obaid A.S. (2014). Effect of foliar fertilizers spray, boron and their interaction on broad bean (Vicia faba L.) yield. Scientific Papers Series B. Horticulture L: $8^{\text {th }}$

Kaul, A.K. (1982). Pulses in Bangladesh. Bangladesh Agric. Res. Coun., Farm Gate, Dhaka. pp: 27.

Kaya, C., Tuna, A.L., Dikilitas, M., Ashraf, M., Koskeroglu, S. and Guneri, M. (2009). Supplementary phosphorus can alleviate boron toxicity in tomato. Scientia Horticulturae, 121: 284-288.

Kumar, S., Singh, V. and Solanki, V.P.S. (2009). Effect of boron and phosphorus application on yield and uptake of nutrients in lentil. Annals of Agricultural Research New Series 30: 108-110.

Mallick, R.B. and Raj, A. (2015). Influence of phosphorus, sulphur and boron on growth, yield, nutrient uptake and economics of rapeseed (brassica campestris L. var. yellow sarson). International Journal of Plant, Animal and Environmental Sciences. 5: 22-27.
Marschner, H. (1995). Mineral nutrition of higher plants (2nd Edition). Academic Press Inc. London. pp: 889.

Padbhushan, R. and Kumar, D. (2014). Influence of soil and foliar applied boron on green gram in calcareous soils. International Journal of Agriculture, Environment and Biotechnology. 7: 129-136.

Poehlman, J.M. (1991). The mungbean. Oxford and IBH Publishing Co. Pvt. Ltd., New Delhi, India. pp: 14-27.

Rana, K.S., Rana, D.S. and Gautam, R.C. (2005). Influence of phosphorus, sulphur and boron on growth, yield, nutrient uptake and economics of Indian mustard (Brassica juncea) under rainfed conditions. Indian Journal of Agronomy. 50: 314-316.

Singh, A P., Singh, M.V., Sakal, R. and Choudhary, K. (2006). Boron nutrition of crops and soils of Bihar, IISS, BhopalRAU, Pusa, Bihar. Technical Bull. 9: 1-70.

Singh, B.P. and Singh, B. (1994). Response of French bean to phosphorus and boron in acid Alfisols in Meghalaya. Journal of the Indian Society of Soil Science. 38: 769-771.

Subedi, H. and Yadav, D.N. (2013). Mungbean [Vigna radiata (L.) wilczek] productivity under different levels of micro fertilizers loading in Chitwan Nepal. International Journal of Agricultural Science and Research. 2: 1-7.

YuFan, H., LongBin, H., XiaoLong, Y. and Hong, L. (2012) Effects of phosphorus and boron coupled deficiency on soybean growth, phosphorus, boron uptake and the genetic variations. Journal of South China Agricultural University.33: 129-134.

\section{How to cite this article:}

Nidhi Kamboj and Malik, R.S. 2018. Influence of Phosphorus and Boron Application on Yield, Quality, Nutrient Content and Their Uptake by Green Gram (Vigna radiate L.). Int.J.Curr.Microbiol.App.Sci. 7(03): 1451-1458. doi: https://doi.org/10.20546/ijcmas.2018.703.173 